\title{
Entering into a community- university collaboration: Reflections from Dig Deep Farms
}

\section{FoodDignity}

\author{
Marty Neideffer * \\ Alameda County Sheriff's Office
}

Submitted April 11, 2018 / Published online July 18, 2018

Citation: Neideffer, M. (2018). Entering into a community-university collaboration: Reflections from Dig

D eep Farms. Journal of A griculture, Food Systems, and C ommunity D evelopment, 8(Suppl. 1), 23-25.

https:/ / doi.org/ 10.5304/ jafscd.2018.08A.011

Copyright @ 2018 by the Author. Published by the Lyson Center for Civic Agriculture and Food Systems. Open access under CC BY license.

W e found a way to grow carrots, to look people straight in the eye and say, "That's good community policing."

It was an unusual process that ultimately led the Alameda County Sheriff's O ffice in San Lean$\mathrm{dro}$, Califormia to become one of the five community sites across the country participating in the Food D ignity Research project. Signing on to that project opened a new door for us to execute the vision we had for our work in community food production as part of community policing. The most beneficial aspect of it was to be with people who were like-minded and didn't think we were crazy.

In 2009, elements of the Alameda County Sheriff's O ffice and the leadership of the Alameda County Deputy Sheriffs' Activities League, Inc., (a nonprofit corporation established to leverage crime prevention efforts of the sheriff's office), came to a conclusion: poverty, in all its various aspects, is a

* Captain Marty Neideffer, Alameda County Sheriff's Office, Dig D eep Farms (http:/ / www.digdeepfarms.com), Alameda County D eputy Sheriff's Activity League; Ashland/ Cherryland, California, USA; +1-510-667-7595; mjneideffer@ acgov.org root driver of crime. Therefore, to credibly address crime in the poor, underserved communities of Ashland and Cherryland, we had to first address the issue of poverty.

It's important to note that, at this point, "elements" of the sheriff's office and "the leadership" of the D eputy Sheriffs' Activities League (DSAL) amounted primarily to two people-myself and a young, dynamic community organizer named Hilary Bass.

I started the DSAL in 2004 when, as a deputy working as a school resource officer, I recognized the need for low-cost recreational and enrichment activities for local low-income kids. I began working with Hilary soon thereafter. She began her career in Ashland as the resident services coordinator for Mercy Housing and later served as the youth leadership coordinator for the Alameda County Community Action Program (ACAP). Through the D SAL, I developed funding for youth activities that connected kids with sheriff's deputies. Hilary stretched those dollars as far as they would go, creating a Y outh Leadership Council and an assortment of other youth programs. We 
officially joined forces in 2008, when Hilary took a job with the sheriff's office as the program specialist and program director of the D SAL.

On April 17, 2010, we decided to take on poverty directly by starting Dig D eep Farms, a community-based social enterprise that would provide local residents with healthy food products at low cost; it would also provide living wage jobs to people coming out of our jails. We were wildly ambitious. We developed a business plan that had us moving into the black within a year. We designed an egalitarian business model inside and out, one that managed the project with an Urban Agriculture Committee made up of local residents, sheriff's office employees, and Dig D eep Farms personnel. We hired 10 people from the neighborhood to become our first team of urban farmers, none of whom had farmed before. We were a little freaking crazy, but we were off and running.

We believed Dig D eep Farms to be a foundational element of our emerging prototype for $21^{\text {st }}$ century police reform. The success of Dig D eep Farms as a social enterprise was going to be important, but so also would the pain and struggle of a tumultuous start-up process that bound the sheriff's office and the community to a project intended to change systems and improve lives. O ur theory of change as it relates to police reform is simple: if you work with people on what's important to their lives, and you stay committed to their goals with them over time, the people will come to trust you... they may even come to love you.

Dig D eep Farms broke ground with the aid of a US $\$ 15,000$ grant from Kaiser Permanente and a US $\$ 50,000$ grant from the Koshland Fellows of the San Francisco Foundation. We leveraged the funding from Kaiser Permanente up against US\$80,000 from the federal government by way of the American Reinvestment and Recovery Act, and used the US $\$ 95,000$ to hire those 10 community members, most of whom had been involved in the justice system before. We paid them US\$20 an hour.

We used the Koshland money to hire local food activists Hank Herrera as the general manager of Dig D eep Farms and G rey Koleveson as the farm manager. As it would turn out, Hank's genius rested more in his ability to envision a future where local people built a food enterprise that could grab market share and create jobs than in his managerial ability to create it. We never came close to achieving the revenue goals of our business plan. Before long, our money began to run out. We had to cut our urban farmers' pay by half, our community-led steering committee began to fall apart, and our ambitions of turning a profit were downsized to prayers for survival.

This was the point at which we became a community partner in the five-year Food Dignity research project, which would ultimately help lead us to national recognition as a community effort involved in developing a locally sourced and led food system. As an action research project infused with language about systems change and social integrity, what was included in the Food Dignity project seemed like the ideal grant process- one that would allow us to build a system like the one we wanted to build and had envisioned all along.

The community support package that came with the Food Dignity project grant turned out to be a crucial element for the survival of D ig D eep Farms. Those grant funds (which averaged US\$65,000 per year) kicked in as other funding sources ran dry, essentially keeping the project afloat financially and promising some baseline stability for the next five years - a much longer period of time than had been afforded by the grants we'd been pulling in up to that point.

Maybe even more importantly, by agreeing to become part of the Food Dignity research project, a new door swung open for us to enter the world of social activism through community food systems work. Overnight, we became partners with a couple of dozen food systems activists across the nation- each site unique geographically and demographically, each focused on a slightly different core mission and approach, yet all of them committed to community-led change that would increase equitable access to healthy food. It was incredibly valuable to have the Food Dignity partners show solid faith in our project and our people and to experience the partners' willingness to see through the storm to the sincerity of our vision. It gave us a sense of legitimacy and the confidence to push forward.

But being part of the Food Dignity project had its challenges, too. There were several elements of 
the support package part of the grant that didn't entirely square with what we were trying to do.

It took all our energy and resources to build the vision we'd created; to divert any of it out of that process and into someone else's idea of what constituted community support was a hardship for our project. Y et, that was part of our learning experience, too- how to use funds that required us to do a number of different things while we were also developing a business with a social mission. The sum total was that it was still about the best kind of grant we'd ever gotten. Being part of the Food Dignity project made all the difference at a crucial time in our development.

Since the darkest days of our sometimes chaotic start, Dig D eep Farms has replaced its general manager four times, and several supervisors have come and gone. More than 70 individuals have held full- or part-time positions or internships with Dig D eep Farms. Most of those folks came to us after doing time in jail. Many employees and interns went on to find other, better paying jobs. Some were terminated because of poor attendance, work performance, or other issues. Some were terminated because of our inability to understand and manage through their unique circumstances. We've tried to learn from our mistakes.

In 2011, D ig D eep Farms gained access to 5 acres (2 hectares) of county-owned hillside land where we planted a 500-tree orchard. In March 2018, we received funding from Alameda County to dig a well and run irrigation on 10 acres (4 ha) of land owned by the Masonic Homes of Union City. Construction on Dig Deep Farms Food Hub and Commissary Kitchen is due to be completed in July 2018.

The sheriff's office, the D SAL, and Dig D eep Farms are pioneering local efforts on a "Food is
Medicine" model, whereby physicians from Children's Hospital in Oakland are prescribing fresh produce to prediabetic children and their families, and Dig D eep Farms is providing produce deliveries.

Dig D eep Farms is under its most stable management to date, and its nine full-time employees are laying a foundation that will include the creation of more jobs in our emerging local food system.

One final thing: In 2014, Dig D eep Farmsthis urban agriculture social enterprise started by the sheriff's office and joined by a sprawling, sometimes anarchic, network of the formerly incarcerated, hipsters, foodies, doctors, funders, cops, political leaders, county agencies, nonprofits, local residents, and others- was named by the California State Association of Counties as the Golden State's most innovative program. The award offered some official validation that efforts to build a local food system constitute innovative community policing.

I am now a captain, having been promoted twice since we started D ig D eep Farms. I currently oversee the sheriff's office Y outh and Family Services Bureau, which includes a sworn and professional staff of 44 devoted individuals, all of whom are dedicated to neighborhood-building and innovative community policing.

We are changing the way people view policing and the way they view food systems. We're making people understand that these are intrinsically connected. D ig D eep Farms and the Food Dignity research project have been key components in our efforts. We will keep putting one foot in front of the other, with the understanding that the journey is the destination. 